\title{
Discurso etnográfico e representação na ficção africana de língua portuguesa: notas sobre a recepção crítica de Mia Couto e o projeto literário de Ruy Duarte de Carvalho
}

Anita Martins Rodrigues de Moraes

Pós-doutoranda (USP-FAPESP)

RESUMO: O PRESENTE TRABALHO INVESTIGA AS NOÇÕES DE REPRESENTAÇÃO IMPLICADAS NO USO DE MATERIAIS ETNOGRÁFICOS PARA ESTUDO DAS LITERATURAS AFRICANAS DE LÍNGUA PORTUGUESA. ANALISA, DE INÍCIO, COMO ESTA EXPECTATIVA DE RETRATO SE INSINUA NA RECEPÇÃO CRÍTICA DO ROMANCE TERRA SONÂMBULA (1992), DO MOÇAMBICANO MIA COUTO. PROPÕE, ENTÃO, POR MEIO DA ANÁLISE DO ROMANCE OS PAPÉIS DO INGLÊS (2000), QUE O PROJETO LITERÁRIO DO ANGOLANO RUY DUARTE DE CARVALHO RESISTE A ESTE TIPO DE EXPECTATIVA, PROBLEMATIZANDO-A.

ABSTRACT: THIS WORK INVESTIGATES THE NOTIONS OF REPRESENTATION IMPLIED IN THE USE OF ETHNOGRAPHICAL MATERIAL IN THE PRODUCTION OF AFRICAN LITERATURES OF PORTUGUESE LANGUAGE. INITIALLY, IT ANALYSES HOW THIS EXPECTATION IS INSINUATED IN THE CRITICAL RECEPTION OF THE NOVEL TERRA SONÂMBULA (1992), BY THE MOZAMBICAN WRITER MIA COUTO. THROUGH THE ANALYSIS OF THE NOVEL OS PAPÉIS DO INGLÊS (2000), BY RUY DUARTE DE CARVALHO, IT IS THEN ARGUED THAT THE LITERARY PROJECT OF THIS ANGOLAN WRITER RESISTS SUCH A CRITICAL RECEPTION.

PALAVRAS-CHAVE: LITERATURA E ANTROPOLOGIA, ESCRITA E ORALIDADE, REPRESENTAÇÃO, LITERATURAS AFRICANAS, RUY DUARTE DE CARVALHO, MIA COUTO.

KEYWORDS: LITERATURE AND ANTHROPOLOGY, ORALITY AND LITERACY, REPRESENTATION, AFRICAN LITERATURES, RUY DUARTE DE CARVALHO, MIA COUTO. 
Em Cartas a um jovem escritor, dentre as técnicas de construção ficcional que considera particularmente interessantes, Vargas Llosa menciona o "dado escondido". Para o escritor, a estratégia de ocultar informações, quando levada a cabo de maneira inteligente, pode capturar o leitor, demandando dele a disposição a imaginar o que a narrativa oculta. Vargas Llosa apresenta interessantes exemplos desta estratégia de "narrar calando", com destaque para a obra de Hemingway, mencionando o conto "Os assassinos" e o romance O sol também se levanta. Depois de tratar do "dado escondido" como recurso escolhido por alguns escritores, Llosa desenvolve uma interessante reflexão acerca da inevitabilidade do implícito, do não dito, em toda narrativa:

A parte escrita de qualquer romance não passa de um trecho ou fragmento da história que conta: a história plenamente desenvolvida, abrangendo todos os elementos sem exceção - pensamentos, gestos, objetos, coordenadas culturais, material histórico, psicológico e ideológico e tudo mais que pressupõe e contém a história integral -, cobre um terreno infinitamente maior do que o explicitamente palmilhado no texto, maior do que aquele que qualquer escritor - mesmo o mais profícuo e loquaz, com o menor pendor para a economia narrativa - seria capaz de cobrir (LLOSA, p. 158).

O dado escondido torna-se, além de um recurso particular que alcança certos efeitos, uma estratégia geral e inevitável própria de todo texto ficcional. Dizer tudo é da ordem da impossibilidade, o leitor deve lidar com os não ditos para continuar sua leitura. Podemos pensar que muitos dos dados implícitos do texto são informações desnecessárias porque óbvias dentro de certas "coordenadas culturais" partilhadas entre autor e leitor. Nesse sentido, a categoria do narratário, ou seja, a ideia de que há um leitor imaginado pela narrativa (Cf. CULLER, p. 88), pode ser útil. Se o escritor espera que seu livro seja lido por alguém que conhece seus costumes, dificilmente se demorará em descrevê-los. Dependendo da expectativa de público, o autor escolhe o que lhe parece necessário dizer ou não, e como. É certamente por isso, pelas lacunas inevitáveis do texto, que a produção de uma época distante ou de uma cultura distinta torna-se obscura, demandando de maneira mais intensa referências externas para que certas lacunas sejam de alguma maneira "preenchidas". 
Em "A literatura e a vida social" (Literatura e Sociedade), Antonio Candido, refletindo sobre como certos fatores externos ao texto podem ser relevantes para sua compreensão, traz como exemplo um poema Inuit, falado pelas mulheres quando da volta dos homens depois de caçadas bem sucedidas (CANDIDO, 2000, p. 28). Sem este dado externo, relativo à situação concreta de execução do poema, sua carga semântica vê-se comprometida. Podemos pensar que Candido, como Llosa, chama a atenção para a situação concreta de produção e recepção do texto, entendendo a literatura (no caso de Candido, tomada em sentido amplo) como uma forma de comunicação. Os sentidos do texto não estão nele contidos, mas se produzem no jogo com o receptor, dependendo, assim, de recursos por ele mobilizados. Os sentidos do texto dependem, portanto, de seu "uso".

Vargas Llosa segue sua reflexão sobre o dado escondido tratando dos limites ou equívocos da representação realista: sugere que a expectativa de que a ficção corresponda à realidade, retratando-a de forma objetiva, costuma supor a possibilidade de que tudo seja dito. Llosa se vale da brincadeira do romancista Claude Simon que, "para sublinhar a inevitável natureza parcial de todo discurso narrativo (...) - com a intenção de ridicularizar a pretensão da literatura 'realista' de reproduzir a realidade -, lançava mão de um exemplo: a descrição de um maço de cigarros Gitanes" (LLOSA, p. 159). Para dar conta deste objeto, o escritor teria que tratar não apenas de sua dimensão material, suas cores, tamanho, etc., como de sua origem, do processo de produção e comercialização, além de lidar com as projeções e desejos envolvidos no consumo do produto, deveria tratar ainda de seu efeito na saúde do fumante, etc. O que Claude Simon pretende com essa brincadeira, na perspectiva de Llosa, é defender que "a descrição de qualquer objeto, por mais insignificante que seja, desenvolvida de maneira totalizadora, leva pura e simplesmente a uma pretensão utópica: a descrição do universo" (LLOSA, p. 160). A inevitabilidade do dado escondido relaciona-se aos limites da representação, a disjunção entre palavra e coisa, interessantemente conduzindo Llosa a se aproximar de certas proposições de Iser sobre os "vazios do texto", vazios estes responsáveis pelo "jogo" que se instala entre o leitor e o texto ficcional. ${ }^{1}$ A expectativa de que uma obra de ficção se faça espelho de determinada realidade

1 Deste teórico, conferir "O jogo do texto" (In COSTA LIMA, 2002, p. 105-118). 
extradiscursiva surge equivocada por esquecer que os sentidos do texto são produzidos no jogo da leitura, têm participação do leitor, serão frutos de sua imaginação mobilizada pela estrutura - para Iser (e Llosa, como vimos) necessariamente incrustada de vazios - do texto.

2. A discussão levada a cabo por Llosa sobre o "dado escondido", que reivindica o caráter lacunar de todo texto ficcional, chamando a atenção para sua instabilidade e contingência semântica, faz-se oportuna para pensarmos nas possibilidades de encontro entre literatura e etnografia no âmbito da produção e recepção das literaturas africanas. Podemos, de início, perguntar se o recurso a materiais etnográficos não seria uma maneira de se recolherem informações úteis para que o leitor estrangeiro possa dar conta de algumas das "coordenadas culturais" subentendidas no texto. Ao estudioso de literaturas africanas caberia, assim, a tarefa de obter e fornecer informações relevantes para a compreensão de certas práticas culturais e concepções de mundo subentendidas na ficção, auxiliando o leitor estrangeiro a se localizar num mundo que lhe é estranho.

Têm sido recorrentes os estudos que se voltam à etnografia empreendida por Junod dos povos do sul de Moçambique tendo em vista compreender aspectos da ficção de Mia Couto, ou seja, tendo em vista entender as alusões presentes em sua obra a práticas culturais tradicionais africanas. Como exemplo deste tipo de abordagem, vale lembrar o exaustivo trabalho de Fernanda Cavacas, especialmente Mia Couto: acrediteísmos e Mia Couto: pensamentos e improvérbios, em que a estudiosa se empenha em estabelecer pontes entre as tradições moçambicanas e a ficção coutiana. No primeiro livro, estabelece paralelos entre crenças/costumes tradicionais (a partir de etnografias e registros de missionários) e fragmentos de obras de Mia Couto; no segundo, entre provérbios tradicionais (também recolhidos por antropólogos e missionários) e construções frasais coutianas similares.

O trabalho do pesquisador que escolhe essa espécie de abordagem tornase "esclarecer" quais costumes e formas de pensamento tradicionais se veem representados na produção literária coutiana e passariam irreconhecíveis para o leitor estrangeiro. Infere-se, por vezes, que o valor dessa produção atrelase justamente a uma espécie de função documental: a ficção coutiana encontrando valor na medida em que representar costumes africanos, em que 
permitir o contato com a "África tradicional". O objeto de desejo do leitor estrangeiro (e talvez não só) parece ser esta África a que a ficção coutiana poderia dar a conhecer.

Podemos nos perguntar, então, se, nesse movimento, o estudioso não abandonaria uma abordagem da obra literária enquanto forma de comunicação (integrada a um contexto, a um sistema de comunicação que inclui comunicador, comunicado e comunicando, nos termos de Antonio Candido²), necessariamente instável semanticamente, deixando-se conduzir por aquela pretensão utópica de que fala Llosa. De outra maneira: ao recorrer a etnografias para conhecer melhor os costumes e a visão de mundo das personagens representadas na ficção, o estudioso arrisca-se a corroborar uma expectativa de espelhamento entre ficção e realidade. Ao esperar que a ficção africana dê a conhecer a África (ou Moçambique, Angola), ver-se-ia empenhado em buscar informações científicas sobre as sociedades deste continente (ou destes certos países) de maneira a apreender a "verdade" do texto. Recorrer ao discurso antropológico pode corresponder a uma expectativa de referencialidade estabilizadora dos sentidos do texto, como se correspondessem a uma realidade extradiscursiva que se faz plenamente revelada pelo estudioso. Assim, o recurso a materiais etnográficos submeteria a literatura à ciência ou, mais precisamente, à "realidade" que se supõe revelada pelo discurso da ciência, realidade esta supostamente "verificável". Se a inevitabilidade do dado escondido nos leva a pensar que o leitor tem uma posição ativa na construção do significado, a utopia da representação realista de que fala Llosa supõe que os sentidos se produzem na relação entre texto e "realidade", prescindindo do leitor. Os sentidos do texto se veriam "revelados" na medida do maior conhecimento da realidade a que o texto se vincula - afinal, parecem confundir-se justamente com esta "realidade". Ao estudioso caberia polir o texto-espelho, esclarecendo ao leitor comum o que o texto "realmente" quer dizer, ou "reflete".

2 "Como se vê, não convém separar a repercussão da obra da sua feitura, pois, sociologicamente ao menos, ela só está acabada no momento em que repercute e atua, porque, sociologicamente, a arte é um sistema simbólico de comunicação inter-humana, e como tal interessa ao sociólogo. Ora, todo processo de comunicação pressupõe um comunicante, no caso o artista; um comunicado, ou seja, a obra; um comunicando, que é o público a que se dirige; graças a isso define-se o quarto elemento do processo, isto é, seu efeito." (CANDIDO, 2000; p. 20) 
Podemos nos perguntar também se ficção e discurso etnográfico não se aproximariam: é comum que, mesmo diante de um romance ou um conto, a expectativa do leitor estrangeiro diante das literaturas africanas seja de que estas deem a conhecer sociedades distintas da sua, empurrando o literário ao domínio da etnografia. Este deslizar da ficção para a etnografia pode ocorrer já no âmbito da produção: o projeto literário consistindo na elaboração de um retrato dos costumes e das cosmovisões das sociedades africanas para recepção estrangeira. Assis Jr., autor de $O$ segredo da morta: romance de costumes angolenses, de 1936, abre seu romance com uma nota de advertência, na qual afirma ser o livro destinado àqueles que se interessam pelo "conhecimento das coisas da terra", seu propósito sendo "divulgar tudo aquilo 'que o indigena tem de mais puro e são na vida'” (ASSIS Jr., p. 32). Considerado por Rita Chaves (1999) o romance inaugural do sistema literário angolano, O segredo da morta nos faz levantar a questão: o percurso do romance angolano imbrica, desde suas primeiras manifestações, discurso literário e científico, atribuindo ao romance a função de dar a conhecer o "indígena" (seus costumes, sua visão de mundo)? Haveria uma associação mais imediata com a antropologia e a etnografia na medida em que a estas disciplinas se atribuiu, durante bastante tempo, a tarefa de dar a conhecer ao mundo ocidental (urbano) sociedades tidas como "primitivas" porque "iletradas", categorias em que as sociedades tradicionais africanas se viram incluídas? Poderíamos ampliar esta hipótese para outras literaturas africanas, como a moçambicana? Havendo estas possibilidades, importa ainda indagar: se tanto no âmbito das expectativas de certos escritores africanos como da crítica especializada pode ser notada uma disposição a aproximar discurso ficcional e etnográfico, como, concretamente, os escritores têm produzido esta aproximação na composição de seus textos e como os estudiosos têm se valido de materiais etnográficos para a elaboração de suas interpretações? Esta aproximação se restringiria a informações sobre os costumes e a visão de mundo de certas sociedades tradicionais que se fazem referidas na literatura e decodificadas pelos estudiosos, produzindo-se um efeito naturalista, ou afetaria as próprias estratégias de composição? Ou inda: inscreve-se completamente no paradigma naturalista ${ }^{3}$ ou o modifica?

3 Recorro aqui a uma acepção lato senso de naturalismo, na esteira de Tal Brasil, qual romance?, de Flora Süssekind. Para esta estudiosa, o naturalismo se repete na literatura brasileira: "a primeira vez 
3. A leitura de etnografias e de antologias do conto ou do provérbio tem sido prática corrente tanto entre aqueles que se dedicam ao estudo da ficção produzida nos países africanos como entre escritores - havendo inclusive escritores e estudiosos de literatura ocupados do registro destas formas discursivas, como o escritor angolano Óscar Ribas ${ }^{4}$ e o estudioso moçambicano Lourenço do Rosário ${ }^{5}$. Na opinião de Ana Mafalda Leite, a investigação das modificações operadas nos gêneros literários de matriz europeia quando em contexto africano tem sido a abordagem mais frequente no âmbito dos estudos das literaturas africanas: "Uma das questões mais permanentes nos estudos críticos africanos no decorrer das últimas décadas tem a ver com a demonstração das relações que a literatura africana, escrita em línguas europeias, estabelece com as fontes indígenas orais" (LEITE, p. 35). O "dado escondido" então insistentemente explicitado seria de ordem genológica: se o receptor está distante das manifestações culturais tradicionais africanas, de seus gêneros discursivos como o conto oral e o provérbio, a ele faltarão elementos para atentar a uma possível mescla entre os gêneros da tradição escrita ocidental e gêneros das tradições orais africanas. Ao estudioso caberia assim, não apenas recolher informações sobre os costumes e a visão de mundo das sociedades tradicionais africanas, mas especialmente investigar as formas discursivas que vigoram nessas sociedades e afetam (esta é a proposição bastante geral) a literatura escrita.

Ana Mafalda Leite, em "Gêneros orais representados em Terra Sonâmbula”, propõe que o conto oral e o provérbio são incorporados no romance coutiano definindo sua estrutura. Nota-se, já pelo título de seu estudo, que não se trata de investigar, pelo menos a princípio, como Moçambique é representado no

como estudos de temperamento, a segunda como ciclos romanescos memorialistas, a terceira como romances-reportagem. Ou ainda, a primeira vez nas últimas décadas do século passado, a segunda na década de Trinta, a terceira nos anos Setenta"( SÜSSEKIND, p. 40). Süssekind argumenta que a literatura, nestes três momentos, se nega "enquanto ficção, enquanto linguagem, para ressaltar o seu caráter de documento, de espelho ou fotografias do Brasil” (SÜSSEKIND, p. 37).

4 Óscar Ribas publicou, entre outros trabalhos, Missosso: Literatura tradicional angolana, em 1961, e o romance Uanga (feitiço), em 1951. Para um cuidadoso estudo de sua obra, especialmente do romance mencionado, conferir "Óscar Ribas: Tradição e Pudor na busca da Identidade Nacional”, de Rita Chaves (CHAVES, 1999; p. 131-155).

5 Em A narrativa africana de expressão oral (1989), Lourenço do Rosário registra, traduz para o português e analisa contos tradicionais em língua cisena da região do Vale do Zambeze (Moçambique). 
romance, mas sim como certos gêneros orais são representados. A estudiosa se propõe a explicitar os gêneros discursivos imbricados na ficção coutiana, sugerindo relações de interdiscursividade ou, como sugere ser mais apropriado dizer, intersemioticidade (já que, em sua perspectiva, trata-se de relações entre códigos da oralidade e da escrita, incluindo gestos rituais, motivos, símbolos). A relação do texto com o real não seria especular, mas meditativa: "O texto literário deve ser olhado já não como um espelho reprodutor de elementos culturais, mas antes como um campo prismático de interação entre discursos culturais e literários. A esta luz pode-se descrever a literatura como um processo de meditação sobre a cultura" (LEITE, p. 38). A estudiosa sugere ainda que os estudos da oralidade na escrita africana têm se ocupado especialmente de uma textualidade manifesta, o que seria detectar gêneros e técnicas narrativas da tradição oral na escrita, havendo, porém, a necessidade de complementar esta abordagem com o estudo de uma textualidade não manifesta, ou seja, "dos sentidos culturais subjacentes a esta representação" (LEITE, p. 38). No estudo do romance Terra Sonâmbula, Leite busca lidar com esta dupla perspectiva: descrever a representação de gêneros orais, enquanto textualidade manifesta que revela a "sobrevivência e adaptação dos gêneros orais no romance moderno" (LEITE, p. 39); e "aferir da intencionalidade subjacente a essa representação, ou seja, o modo de enquadrar valores específicos da cultura oral tradicional moçambicana no contexto actual de modernização e da escrita" (LEITE, p. 39). No âmbito dessa "intencionalidade subjacente" haveria a convocação de um "receptor simbólico", o ouvinte do contador de estórias. Para a estudiosa, as estratégias de inscrição da oralidade na escrita teriam como efeito mais radical justamente a demanda de um receptor ouvinte, mesmo que simbólico.

Atentar para o horizonte de expectativa dos gêneros pode ser um desdobramento da suposição de que os sentidos do texto são um suplemento produzido na interação da leitura, dependendo, portanto, das referências do leitor. A estudiosa interpreta a construção desse "receptor ouvinte" como uma estratégia de diminuir "a distância de registro genérico entre um potencial receptor moçambicano, ou africano" (LEITE, p. 53). Ou seja: "a escolha de Mia Couto pressupõe ou tende a responder a uma apetência, ainda que 'simbólica', do público leitor/ouvinte moçambicano". (LEITE, p. 53) Voltarse para a "oratura" na composição de seu romance delataria, assim, uma preferência do autor pelo público moçambicano/africano. 
A estudiosa segue traçando diferentes possibilidades de recepção do romance, já que este pode (e costuma ser) lido por estrangeiros. Diferencia, então, o leitor indígena do alienígena: para o receptor indígena o romance tenderia a produzir efeitos de reconhecimento/integração; para um leitor alienígena, estranheza/diferenciação. Dependendo das referências do leitor, de seu horizonte de expectativas (Leite faz uso do conceito de Jauss), do choque ou conforto promovido pelo texto, então se produzem os sentidos deste, na leitura. Em certa medida, o estudo de Ana Mafalda Leite se torna a tentativa de conduzir o leitor alienígena da estranheza ao reconhecimento, tornando-se capaz de notar certas referências a práticas culturais e concepções de mundo a ele alheias, e de notar o aproveitamento de formas discursivas próprias das tradições africanas na escrita. Após a leitura do texto de Leite, o leitor seria capaz de perceber que "o imaginário cultural da sociedade moçambicana" (LEITE, p. 55) está reposto no romance, não se limitando à invenção do autor, a um registro maravilhoso.

Ainda que algumas ressalvas possam ser pertinentes quanto à proposição de Leite - especialmente no que tange a uma subentendida homogeneidade cultural moçambicana em noções como "imaginário cultural da sociedade moçambicana" e "leitor moçambicano" - o que me interessa notar aqui é que, ao descrever a representação de gêneros tradicionais, a estudiosa se vale especialmente da etnografia de Junod. É recorrendo a Usos e costumes bantos que a estudiosa encontra informações para tratar dos gêneros da "oratura moçambicana", decisivos em sua abordagem. As categorias de Junod são aproveitadas, especialmente a distinção entre "três tipos de gênero": a poesia didática ou sentenciosa (provérbios, máximas e enigmas), a poesia narrativa (os contos) e a poesia lírica nos cantos. Leite lembra que Junod sugere a possibilidade da mistura entre os gêneros, especialmente entre os dois primeiros (apesar de também ser frequente a presença de cantos nos contos). É exatamente esta mistura que a estudiosa se empenha em flagrar na escrita coutiana, já anunciada, portanto, em práticas da "oratura". Além dos gêneros orais, e de subgêneros (como a distinção entre contos de animais, de pessoas, de seres fantásticos e os contos verdadeiros), a estudiosa encontra em Junod informações acerca de certas concepções tradicionais: "Segundo ainda informação de Junod (1974:305), algumas aves são objeto de ideias supersticiosas, nomeadamente esta, o mampfana, aquele que faz parar os viajantes" (LEI- 
TE, p. 43). Além deste dado, Ana Mafalda Leite apresenta outro: o tabu que envolve os gêmeos. Ou seja, certas concepções envolvendo o nascimento de gêmeos também se encontram descritas por Junod: "E passo a citar Henri Junod: 'Esta potência que causa o relâmpago e a morte está ligada a mãe de maneira muito especial ao nascimento dos gêmeos, de modo que a mãe deles é chamada Tilo, o Céu, e crianças, Baana bá Tilo, Filhos do Céu"' (LEITE, p. 43). Essas e outras (como os anões caídos do céu e os animais que falam) referências ao imaginário cultural ronga surgem no artigo de Ana Mafalda Leite como atestado de que "parte significativa do material temático fabuloso de Terra Sonâmbula se fundamenta nas tradições dos povos do sul de Moçambique (...)" (LEITE, p. 44).

Gostaria, aqui, de levantar a seguinte questão: a etnografia de Junod não forneceria tanto à estudiosa como ao escritor elementos para a composição de seus textos? Ou seja, não seria o caso de perguntar se Mia Couto teria se valido da etnografia de Junod como material para a composição de seu romance, à maneira do uso que fez Mário de Andrade dos mitos indígenas registrados por Koch-Grünberg na composição de Macunaima? Afinal, tanto um como outro (Mário de Andrade e Mia Couto) não são integrantes das culturas indígenas, antes se valem de alguns de seus materiais para a criação ficcional. Importa então, perguntar: certa literatura africana (como certa literatura brasileira) não vem se produzido num diálogo e num aproveitamento de materiais etnográficos como matéria prima? Não estaríamos diante de um círculo fechado, de uma espécie de trama discursiva autorreferencial envolvendo etnografia, literatura e crítica literária? Se for verossímil a hipótese de que o escritor moçambicano se volta a etnografias para compor sua representação das práticas culturais tradicionais e que esta representação se vê reconhecida pelo leitor especializado ao se voltar também a etnografias (produzindo-se, por vezes, um efeito naturalista, ou seja, de verificação da "veracidade" da ficção), o que teríamos seria toda uma armação cuja base não parece ser a "realidade" (talvez nunca seja), mas um texto etnográfico

6 Esta hipótese se faz verossímil especialmente por conta da proximidade entre passagens do romance de Mia Couto e da etnografia de Junod (que inclusive não se limita às passagens apontadas por Ana Mafalda Leite). Além deste dado verificável, nota-se que o escritor mencionou já, em entrevistas e palestras, ter esta leitura como referência (Cf. entrevista concedida por Mia Couto à Revista Abril na página http://revistabrasil.org/revista/artigos/celina3.html - acesso em 30/07/2009). 
(ou vários). O texto coutiano antes aproveita textos registrados e incorporados ao texto do etnógrafo do que configura um diálogo imediato com a as manifestações da oratura - seu diálogo, seria o caso de pensar, se dá via etnografia, com a etnografia. O texto de Ana Mafalda Leite, por sua vez, aproveita-se do texto etnográfico de Junod para comprovar a representação das tradições moçambicanas no romance coutiano (vale lembrar que os sentidos dos motivos, símbolos e costumes tradicionais são, no geral, explicitados no romance de Mia Couto, o resultado da abordagem de Ana Mafalda Leite sendo antes a "comprovação" da "autenticidade" dessas representações que o esclarecimento de seus sentidos). O que se toma por "imaginário cultural moçambicano" não seria este sedimentado de discursos, dos discursos dos "informantes" integrados ao discurso do etnógrafo, recuperado por escritores e estudiosos?

Não se trata de sugerir uma falsificação, tampouco que não exista um (ou mais de um) "imaginário cultural" em Moçambique, mas de notar uma dinâmica entre textos e de sugerir que os gêneros tradicionais, como o provérbio e o conto oral, quando presentes no texto literário ou crítico são, geralmente, apanhados a partir de algum registro escrito que é, por sua vez, sempre uma tradução. Talvez seja o caso de não tomar o texto etnográfico e, especialmente, os registros dos textos orais africanos traduzidos para línguas europeias, como transparentes (mesmo quando o autor das traduções seja o próprio escritor, o que, na verdade, é raro no âmbito das literaturas africanas de língua portuguesa). Seriam, antes, uma espécie de textos-alicerce da armação discursiva em que se inscreve parte das literaturas africanas e sua recepção crítica. Não seria esta textualidade subjacente à ficção e à crítica literária algo a ser explicitado? O projeto literário do escritor angolano Ruy Duarte de Carvalho não poderia ser lido nessa chave? No caso de sua produção ficcional, não teríamos ficções que expõem, incorporando à cena narrativa, a elaboração/ artefatualidade do texto etnográfico?

4. Como já foi dito, o recurso a etnografias e antologias do conto e do provérbio por parte dos estudiosos de literaturas africanas é bastante comum quando se trata de abordar as relações com as tradições orais africanas - por sua vez a abordagem interpretativa mais frequente, sugestiva do entrelaçamento entre escrita e oralidade no texto literário. Parece-nos, no entanto, que 
se por um lado o amplo vigor desta leitura pode resultar de seu largo alcance explicativo, por outro pode delatar a adesão, por parte da crítica especializada, a projetos literários e políticos que norteiam certa produção literária africana. $\mathrm{O}$ risco, aqui, é tanto repetir e naturalizar projetos (ou seja, tomar por fenômeno cultural o que antes é projeto de cunho político-cultural), como obrigar que as obras digam sempre o mesmo - não importa qual romance, conto ou poema, a chave interpretativa será a da mescla entre África e Europa (para uma discussão de problemas semelhantes no âmbito da América Latina, conferir "Além da literatura", de Marcos Natali).

Apesar dos resultados serem comumente semelhantes - concluir-se que a obra concilia escrita e oralidade, assegurando a sobrevivência, mesmo que transformada, das culturas tradicionais na modernidade - há diferenças que merecem nota. Se Ana Mafalda Leite entende (em diálogo com Ato Quayson) que a literatura deve ser entendida como "um campo prismático de interação entre discursos culturais e literários” (p. 38), campo este em que talvez seja necessário (esta é minha sugestão) destacar os textos etnográficos, há abordagens muito próximas da sua que entendem esta "interação" como um reflexo da sociedade moçambicana. A hibridez do texto coutiano parece corresponder, na perspectiva de Patrícia Vieira, a uma sociedade híbrida. Ou seja, a tese do encontro de gêneros pode deslizar de uma abordagem ocupada da relação entre texto e leitor para um olhar ocupado das relações entre texto e realidade referida. De outra maneira: atentar para os gêneros discursivos pode tanto responder a uma atenção para as lacunas do texto (os dados escondidos de que fala Llosa), portanto a uma tentativa de restaurar um contexto literário mais próximo do contexto de produção, como responder a uma tentativa de apreensão dos sentidos do texto, que corresponderiam, mesmo que alegoricamente, a certa realidade social (sendo, desta forma, estáveis). No caso do artigo "Diálogo, tradução e hibridismo em Terra Sonâmbula", de Patrícia Vieira, uma reflexão acerca do caráter híbrido da identidade moçambicana se faz útil para o entendimento da hibridez do romance, como também para a decodificação de algumas alegorias, como é o caso da personagem Muidinga:

Esta personagem é passível de uma leitura simbólica, como representante do povo moçambicano e do caminho que este terá que percorrer em direcção à 
paz. Tal como Muidinga, o país foi quase destruído pela guerra e necessita de procurar esquecer os traumas do passado para proceder a reconstrução. Caso se considere a criança como sendo Gaspar, filho de Farida e Romão Pinto, a sua identificação com Moçambique torna-se ainda mais pertinente. Fruto de uma violação, agressão frequentemente associada com o colonialismo, a sua existência representa a fusão entre África e Europa, que é uma realidade do território. Muidinga, que circula com à vontade entre histórias de magia e a linguagem escrita, reflecte a esperança na união destas duas culturas que a geração de Kindzu e de Farida não pôde conciliar. O jovem, único dos personagens principais que sobrevive no livro, representa, deste modo, um terceiro espaço híbrido, resultante do processo de colonização. (VIEIRA, p. 90)

A noção de representação parece cambiante: por um lado trata-se de desvendar sentidos alegóricos ou simbólicos que corresponderiam a ponderações sobre a sociedade moçambicana (ou seja, parece que a estudiosa se empenha em desvendar mensagens intencionais no romance, sugestivas de uma reflexão acerca dos rumos do país e mesmo de um projeto coutiano para Moçambique); por outro, de supor que o romance "representa", especialmente Muidinga, a "realidade do território", entendida como a fusão entre África e Europa que teria produzido um "terceiro espaço híbrido".

No primeiro caso, a dimensão performativa ${ }^{7}$ da obra literária se destaca trata-se de inventar/propor/instaurar com a literatura um projeto de nação -; no segundo caso, uma expectativa de reflexo se insinua - a realidade moçambicana sendo híbrida (uma fusão entre África e Europa) encontra uma representação híbrida na literatura (em diversos níveis, da linguagem aos elementos da narrativa). Se a ficção for tomada como correspondendo à realidade moçambicana, a abordagem se situa no âmbito de uma teoria do reflexo (de que a ficção reflete a realidade); na medida em que se entender que certos elementos externos ao texto contribuem para a produção de sentidos contingentes, e que os textos podem significar coisas diferentes mudando-se o contexto,

7 Em Teoria literária: uma introdução, Jonathan Culler propõe, a partir dos "atos de fala" de Austin, a distinção entre linguagem performativa e constativa: "a constativa é uma linguagem que afirma representar as coisas como elas são, nomear as coisas que já estão aí, e a performativa são as operações retóricas, os atos de linguagem, que minam essa afirmação impondo categorias linguísticas, criando as coisas, organizando o mundo em lugar de simplesmente representar o que existe" (p. 101). 
estamos no âmbito de uma estética da comunicação que enfatiza a instância da recepção. A primeira abordagem arrisca sugerir que Moçambique seja uma "nação mestiça", tomando-se a ficção por realidade. Afinal, será que este país pode ser entendido como uma fusão, uma síntese? Podemos pensá-lo como uma mistura homogênea? Esta síntese não seria antes um projeto coutiano para Moçambique? Alguns dados do Senso de 1997 podem ser importantes aqui: 1) apenas $1 \%$ da população moçambicana é branca, mestiça, indiana ou outra, sendo os restantes $99 \%$ de população negra; 2) apenas 6,5 \% têm o português como língua materna, e 39\% são alfabetizados em português. (Cf. FRY 2001: 35). A questão que se coloca então é: como podemos entender as relações entre ficção e realidade sem incorrer em expectativas de espelhamento que arriscam naturalizar o que é construção, a tomar por "realidade do território" uma ficção?

Parece importante notar, portanto, que o estudo das relações entre os gêneros orais e escritos pode também operar com uma expectativa de espelhamento, ainda que mais sofisticada. Ou seja, mesmo não sendo imediata a relação entre ficção e realidade (o estudioso apontando que tal costume representado é real, tal paisagem é real etc.), passando pelo estudo das estratégias de composição, portanto da estrutura da obra, e lidando com camadas de sentido não evidentes (atentando para alegorias, sentidos simbólicos), o estudioso pode ancorar sua leitura em alguma realidade extradiscursiva. De certa maneira, supõe que, caso não encontre esta realidade, os sentidos do texto continuam esquivos. Ou ainda: pode supor que se a interpretação da ficção não levar a uma melhor compreensão do funcionamento da sociedade em que ela se produz, a interpretação não teria chegado a bom termo (ou, no limite, atestaria que a obra literária não tem valor algum).

Seria o caso de suspeitar, então, que não apenas as produções ficcionais que seguem postulados naturalistas mobilizam expectativas de espelhamento entre ficção e realidade. Por vezes, justamente porque se inscreve no registro do maravilhoso, uma produção pode ser lida como reflexo de uma "visão de mundo" ou realidade social particular. Assim, mesmo que o aproveitamento de gêneros da tradição oral na construção ficcional costume coincidir com o abandono de certas estratégias de representação realistas, instaurando um mundo ficcional regido por leis sobrenaturais (não respondendo ao que em geral se entende como realidade no mundo ocidental), essa modificação pode 
ter um efeito naturalista na medida em que se espere ser a representação de uma visão de mundo que assume o sobrenatural como possibilidade. $\mathrm{O}$ potencial de relativização do que seja, então, o "real" pode sim abalar definitivamente os postulados naturalistas (afinal, se existe mais de uma maneira de se entender a realidade, ela não pode ser retratada de maneira totalizante, será sempre uma "realidade" entre outras); porém, caso estes postulados se mantenham, reforça-se certa expectativa de que a África seja da ordem do excepcional, fabulosa, mágica, e que os africanos se caracterizem por uma forma de pensamento particular, não racional. Segundo Antonio Candido, há "cerca de meio século apareceu um modo renovado de encará-los [os "povos primitivos"] como bichos, com todas as ressalvas da ciência e da filosofia. É a teoria de Lévy-Bruhl, segundo a qual a mentalidade do primitivo seria, por assim dizer, qualitativamente diversa, na medida em que subordina a visão do mundo, não a princípios lógicos, como nós, mas a uma espécie de indiferenciação entre sujeito e objeto, entre as categorias e os corpos, de modo a definir um espírito 'pré-lógico', incapaz de abstrair e de observar o princípio de contradição." (CANDIDO, 2000; p. 38) Ao tomar a ficção coutiana como representação de uma "visão de mundo africana" não estaríamos repondo este tipo de tese? Segundo Goody, os famosos contos tradicionais colhidos por antropólogos e missionários na África Ocidental são, “em sua grande maioria, fábulas, que ocupam a posição marginal reservada aos discursos para crianças, e não se prestam para consumo comum do adulto. Representam a mentalidade primitiva apenas na medida em que se poderia considerar, na Europa hoje, Polichinelo representar a modernidade contemporânea" (apud COSTA LIMA, 2009, p. 20). Não seria um equívoco talvez semelhante considerar que contos orais incorporados ao romance coutiano dariam a conhecer uma "cosmovisão tradicional africana" ou "moçambicana"?

Talvez seja o caso de perguntar se tanto a produção quanto a recepção das literaturas africanas não costumam lidar com certas ideias sobre a África, certas representações, imagens, que envolvem este continente e que se produziram ao longo das relações coloniais. Seriam estas representações naturalizadas de África a realidade com que se embatem, representações que, inclusive, não podem ser estabilizadas, já que assumem contornos diferentes em diferentes espaços culturais. Talvez as imagens de África correntes no Brasil, mesmo que não homogêneas, tenham alguns contornos diferentes 
das que circulam em Moçambique, Angola, Portugal, Estados Unidos (para não mencionar os diferentes grupos sociais e mesmo, especialmente no caso africano, sociedades que coabitam estes espaços nacionais). Nesse sentido, podemos pensar que as literaturas africanas tendem a mobilizar no leitor estas representações naturalizadas, suas lacunas sendo preenchidas a partir delas, de maneira a reforçá-las ou as colocar em suspenso (efeito que depende tanto do texto - de seu potencial de sentido - como da leitura). A relação entre o texto ficcional e realidade seria antes com o que o leitor entende por realidade, assim, com as representações sociais naturalizadas de que dispõe, do que com determinada realidade social objetiva. O "real" seria, antes, intersubjetivo. ${ }^{8}$ Não se trata de negar que uma obra literária possa trazer elementos para o estudo de dinâmicas sociais, como faz Antonio Candido, entre outros momentos, em "A dialética da malandragem" (O discurso e a cidade), mas de entender que uma leitura dessa natureza é possível porque o crítico seleciona elementos do texto propondo uma estrutura e estabelece, então, certas analogias entre modelos sociológicos e a estrutura que propõe como constitutiva da obra. Esta não seria reflexo de determinada estrutura social, mas consistiria numa construção do crítico a partir de uma construção ficcional que pode resultar, como os modelos sociológicos pretendem, em recursos para a compreensão de aspectos do real (este já modelado em termos de "realidade social").

5. Da mesma maneira que Terra Sonâmbula, o romance Os papéis do inglês, de Ruy Duarte de Carvalho, estrutura-se como "caixa chinesa" ou "boneca russa", ou seja, nesses romances, "uma história principal gera outra ou outras histórias derivadas” (LLOSA, p. 137). Em Terra Sonâmbula, a alternância

8 Nossa sugestão se desdobra da leitura de "Representação social e mimesis", de Luiz Costa Lima. Neste texto, o teórico propõe que se distinga entre realidade e real: "Se esta, entendida como natureza, é prévia e independente do homem, sua conversão em real se faz através de um processo duplo, paralelo mas distinto: por sua nomeação - que não se restringe a dar nome a partes da realidade - e pela formulação de molduras determinadoras da situação decodificante da palavra". (1981; p. 223) Em sua perspectiva, a mimesis literária lida com este real, cujo precipitado são as representações sociais: "As representações são, por conseguinte, os meios pelos quais alocamos significados ao mundo das coisas e dos seres. Por elas, o mundo se faz significativo. E o choque de significações de imediato resulta do choque de representações" (1981; p. 219). 
de duas narrativas, a que conta de Muidinga e Tuahir e a narrativa de Kindzu (registrada em cadernos que serão lidos por Muidinga), cede a um jogo de contaminações crescente (alcançando, ao final, seu ponto máximo). No romance de Ruy Duarte, a narrativa da invenção da história de Archibald Perkings instaura dois planos narrativos em três distintas temporalidades. Os dois planos são: 1) a história do inglês Archibald Perkings e a 2) história do narrador-personagem em sua busca pelos papéis deste inglês (que inclusive lhe forneceriam elementos para a composição de sua estória). Com relação às temporalidades há: 1) o tempo da narrativa de Perkings (ano de 1923), 2) o tempo da história da busca do narrador-personagem pelos papéis (por volta de um ano e meio), e 3) o tempo presente, de escrita (de 23/12/99 a 01/01/00 - atestados pelos fragmentos de diário). O recurso da boneca russa/caixa chinesa concorre para que se instale uma dimensão metalinguística nas obras, corrosiva de possíveis efeitos naturalistas. No caso d'Os papéis do inglês, à metalinguagem associa-se o recurso intenso a citações, a fragmentação e a imbricação de diferentes modalidades discursivas, de maneira que o leitor se faz constantemente, e por diferentes motivos, impactado com a dimensão artefactual do discurso.

O dispositivo detonador da história já remete a um texto: trata-se de reescrever a história do "branco que odiava as brancas", contada por Henrique Galvão no volume de crônicas Em Terra de Pretos (1929). O narrador-personagem, que remete à própria figura do autor, Ruy Duarte de Carvalho (além de antropólogo como o autor, o narrador-personagem menciona o livro Vou lá visitar pastores como livro seu anterior [Cf. p. 13; p. 24; p. 33]), empenha-se em inventar outra versão desta história, atribuindo ao branco de Galvão novos traços: este se torna Archibald Perkings, um antropólogo inglês que, desiludido no casamento e na profissão, segue para uma região isolada da África. Se já sabemos, pela sucinta crônica, qual será seu fim - cometer o assassinato do grego e, depois de alguns dias, ter um surto de violência seguido de suicídio - suas causas serão descobertas à medida que a história se inventa e se conta. Outros textos serão demandados para esta composição, especialmente "The return", de Joseph Conrad, mas também O coração das trevas e Entreposto do Progresso, do mesmo autor, Viagem ao fim da noite, de Céline, Émaglons, de Henri Michaux, entre outros. Os papéis do inglês faz-se uma trama discursiva cuja opacidade toma o lugar da "África", ou seja, esta não surge como reali- 
dade extradiscursiva acessível via ficção, mas como resultado de uma trama de discursos construída ao longo das relações coloniais. Com esta estratégia, o romance frustra possíveis expectativas de apreensão de uma "realidade" ou "cosmovisão africana", devolvendo ao leitor representações, demandando a percepção de que o que possa entender por “África” não são senão representações naturalizadas. ${ }^{9}$

Há, como no romance coutiano, uma série de vasos comunicantes que ligam as histórias. ${ }^{10}$ Perkings torna-se uma espécie de duplo do narradorpersonagem: os dois buscam "tesouros" cujo rastro foi deixado por seus pais (no caso de Perkings, o tesouro do antigo soba Lobelunga; no do narradorpersonagem, os papéis de seu pai que se misturam aos do inglês); ambos são antropólogos (bastante outsiders, vale notar). Há momentos em que as narrativas parecem se espelhar. Se Perkings se demora admirando os seios da ruiva ("Apenas o peitilho vem aderir-lhe ao corpo, e o peso do tecido revela seios que quase não tem, à solta por baixo, adivinha-o ele e o pai quando estão à mesa e os olhares de ambos convergem para lá e depois se encontram e Archibald cora e confunde os gestos" [CARVALHO, 2000, p. 85]), o narrador admira os da menina que com ele pega carona ("Levei no carro uma das mulheres do Batupo e a filha do Tyinkipa. Fiz a viagem toda com o retrovisor assestado no peito da menina" [CARVALHO, 2000, p. 94]).

Se o menino Perkings vê o pai tendo relações sexuais com a mesma ruiva ("A imagem do pai e da amiga envolvidos na sua fusão não era em si mesma o que the repugnava mais. O que the inspirava um asfixiante horror não era sequer a perturbaça introduzida assim na imagem do pai, era antes a repulsa por sentir que se sujara a si mesmo e ao pai assistindo àquilo, e era também o fascínio do acto, a excitação que o tomava (...)" [CARVALHO, 2000, p. 88]), o narrador encontra, entre os papéis de seu pai,

9 Nesse sentido, encontra-se em sintonia com o gesto do filósofo congolês (Kinshasa) Mudimbe, que em The invention of Africa e The idea of Africa percorre representações construídas no mundo Ocidental a respeito da África, desde os antigos até a atualidade. Vale mencionar também o importante trabalho de Arlindo Barbeitos, voltado para o caso angolano: Angola/Portugal: des identités coloniales equivoques; historicité des représentations de soi et d'autrui. 10 "Devido a essa estrutura, os acontecimentos distintos, articulados em um sistema de vasos comunicantes, intercambiam vivências e entre eles se estabelece uma integração graças à qual os episódios se fundem em uma unidade que não corresponde a meros segmentos justapostos. Existem vasos comunicantes quando a unidade é algo mais que a soma das partes integradas ao episódio, (...)" (LLOSA, p. 165). 
desenhos pornográficos - e então se pergunta o que teria lhe acontecido se os tivesse visto quando menino... ("As figuras de todos aqueles anuncios trocavam entre si a mais desconcertante, e talentosa e humorada - devo reconbecê-lo e tiro o meu chapéu ao finado J.J. - ordem de obscenidades, impropérios e alusões soezes. Siderei." [CARVALHO, 2000, p. 42]). Se Perkings mata o grego, o narrador-personagem deseja matar o próprio primo Kaluter (o título do capítulo em que o narrador encontra seu primo Kaluter é "O grego é que podia ter morrido assim” (CARVALHO, 2000, p. 102)). O narrador-personagem não inventaria uma nova versão da história do inglês para falar de si? Um fragmento de diário parece anunciar este recurso:

Parece levantar-se o vento leste e há uma luz magnífica. Estou a tomar o terceiro copo de café, fumo constantemente, sinto os efeitos de uma gripe que começou pelos brônquios e os óculos bifocais, pousados à minha frente enquanto uso os de ver só ao pé, devolvem-me a imagem dupla, e deformada pela curvadura das lentes, de um sujeito de barbas brancas que escreve debruçado sobre um caderno... até quando? (...) (CARVALHO, 2000, p. 60).

De quem seria esta imagem refletida, duplicada e deformada senão do narrador-personagem (que se mostra ao leitor escrevendo) e do inglês (cujos papéis movem a trama)? O motivo da duplicação parece ecoar a própria estratégia de composição do romance: os fragmentos de diário, que antecedem os nove capítulos do livro, são pequenos textos em itálico antecedidos por datas, que ressoam (duplicam?) o que será narrado. O leitor deve perscrutar seus sentidos, não evidentes, estabelecendo relações com os outros "discursos marcados" que compõem o romance: os "e-mails" ("Então avante, tenho dez dias à minha frente, fará de conta agora que são e-mails, como foi da outra vez com as cassetes para o Filipe, nos Pastores..." (CARVALHO, 2000, 24)) e o "Intermezzo". No Intermez:o (também em itálico, ao meio do livro), temos uma espécie de roteiro para cinema que conta do inglês (trata-se da nova versão de sua história); nos "e-mails" (cuja destinatária se dá a conhecer ao final do livro) temos diversos gêneros imbricados, como a carta, o ensaio, a narrativa de ficção, a historiografia, a etnografia (com transcrição de gravações que apreendem o testemunho de informantes). Esta composição fragmentada e múltipla evidencia, como disse já, o caráter artefactual do texto, boicotando expectativas de transparência. 
Fazendo do inglês de Galvão um antropólogo, o romance estrategicamente trata do período de consolidação da antropologia como disciplina, sugerindo as relações que manteve com as políticas coloniais, com destaque para o capítulo intitulado "Uma imensa fadiga" (p. 45-59). É digno de nota que as posições de Frazer, Radcliff-Brown e Haddon com relação à natureza e às funções da antropologia se veem discutidas no romance. Radcliff-Brown ganha, inclusive, contornos de personagem:

Radcliff-Brown não fazia, manifestadamente, nenhum esforço para agradar às pessoas. Podiam falar para ele, esperar uma resposta, o seu olhar permanecia fixado na distância, não haveria resposta nenhuma. Homem mais brusco era difícil de encontrar, apesar da sua elegante aparência e do modo como se exibe, à maneira de um excêntrico aristocrata inglês. As mulheres, a quem aliás exaspera, diz-se, parece que tinham fortes razões para o odiar e não escapavam, segundo o revelavam, as suas obscuras origens de marçano em Birmingham. Radcliff-Brown deve sentir-se uma espécie de super-homem, e esforça-se, a um ponto que é difícil imaginar, por viver estritamente segundo um plano que a sua razão e a sua vontade traçaram. (...) (CARVALHO, 2000, p. 55).

Sendo o narrador-personagem um antropólogo, o romance encena o processo de elaboração de uma etnografia, evidenciando a dimensão subjetiva de seu trabalho, sua contingência (estar em dado lugar, ouvir e ver certas coisas, não outras) e todas as mediações que o separam (ou ligam) a seu objeto de estudos. O que o romance parece propor é que a etnografia (como a ficção) oferece imagens sempre parciais, precárias, inscrevendo-se num jogo de representações (não havendo "realidade" apreensível fora dele). Este jogo não é, porém, inofensivo. Ao problematizar as relações da antropologia com os colonialismos, ao parodiar e ironizar a literatura colonial, o romance abala representações correntes das sociedades tradicionais africanas. Evidenciando a parcialidade e contingência dessas representações, o romance evita oferecer uma África sobrevivendo na modernidade (numa espécie de redenção final, e feliz); convida, ao contrário, o leitor a suspeitar de suas lentes - das etnografias, dos registros da "oratura" e, ainda, das teorias literárias de que dispõe (que inclusive se valem desses materiais). Evidenciando e encenando a atividade do antropólogo, Os papéis do inglês corrói a base da armação discursiva que sugeri 
anteriormente, desmontando a estratégia (de efeito naturalista) de se recorrer a materiais etnográficos para a "comprovação" da tese de que a "África tradicional" se inscreve na literatura escrita. O romance boicota, assim, a expectativa de que a "ficção africana" seja documento da "realidade africana" (ou, mais modestamente, de que a "ficção angolana" seja reflexo da "realidade angolana”). Ao se contrapor às representações implicadas nas relações coloniais (que, aliás, ainda vigoram), o romance de Ruy Duarte de Carvalho não parece oferecer uma "representação mais verdadeira" da África, de Angola, ou dos kuvales, mas sim a verdade da representação - radical e corrosiva.

\section{Referência Bibliográfica}

ASSIS Jr.. O segredo da Morta: romance de costumes angolenses. Lisboa: Edições 70, 1979.

BARBEITOS, Arlindo. Angola/Portugal: des identités coloniales equivoques; historicité des représentations. Paris: L'Harmattan, 2008.

CANDIDO, Antonio. Literatura e Sociedade. São Paulo: Publifolha, 2000. - A educação pela noite. São Paulo: Ática, 1987. . O discurso e a cidade. São Paulo: Duas Cidades, 1993.

CARVALHO, Ruy Duarte de. Os papéis do inglês. São Paulo: Companhia das Letras, 2007. -Vou lá visitar pastores. Lisboa: Cotovia, 1999.

CAVACAS, Fernanda. Mia Couto: acrediteísmos. Lisboa: Mar Além, 2001. . Mia Couto: pensamentos e improvérbios. Lisboa: Mar Além, 2000.

CHAVES, Rita de Cássia Natal. A formação do romance angolano. São Paulo: FBLP, Via Atlântica, 1999.

COSTA LIMA, Luiz. Dispersa demanda. Rio de Janeiro: Livraria Francisco Alves, 1981. . O controle do imaginário e a afirmação do romance. SP: Companhia das Letras, 2009.

Costa Lima, Luiz (Org.). A literatura e o leitor: textos de estética da recepção. São Paulo: Paz e Terra, 2002.

COUTO, Mia. Terra Sonâmbula. Rio de Janeiro: Nova Fronteira, 1995.

CULLER, Jonathan. Teoria da literatura: uma introdução. São Paulo: Beca, 1999.

FRY, Peter (org.) Moçambique; ensaios. Rio de Janeiro: Editora UFRJ, 2001.

GEERTZ, Clifford. A interpretação das culturas. Rio de Janeiro : LTC, 1989.

JUNOD, Henri. Usos e costumes dos Bantus. Maputo: Arquivo Histórico de Moçambique, 1996. 
LEITE, Ana Mafalda. Literaturas africanas e formulações pós-coloniais. Maputo: Imprensa Universitária/UEM, 2003.

LLOSA, Vargas Mario. Cartas a um jovem escritor. Rio de Janeiro: Elsevier, 2006.

MUDIMBE, V. Y.. The idea of Africa. Bloomington e Indianápolis: Indiana University Press, 1994.

The invention of Africa. Bloomington e Indianápolis: Indiana University Press, 1988.

NATALI, Marcos P. . Além da literatura. Revista Literatura e Sociedade (USP), v. 9, p. 30-43, 2006.

RIBAS, Óscar. Missosso: Literatura tradicional angolana. Luanda: Tipografia Angolana, 1961.

- Uanga (feitiço). Luanda: União dos Escritores Angolanos, 1985.

RODRIGUES, Selma Calasans. O fantástico. São Paulo: Ática, 1988

ROSÁRIO, Lourenço Joaquim da Costa. A narrativa africana de expressão oral: transcrita em português. Lisboa: Instituto de Cultura e Língua Portuguesa; Luanda: Angolê, 1989.

SÜSSEKIND, Flora. Tal Brasil, qual romance? Rio de Janeiro: Achiamé, 1984.

VIEIRA, Patrícia. "Diálogo, tradução e hibridismo em Terra Sonâmbula". In Revista de Estudos Africanos e Portugueses (EPA), n. 42, 2003. 